\title{
Medullary Thyroid Carcinoma Clinical Regional Lymph Nodes TNM Finding v8
}

National Cancer Institute

\section{Source}

National Cancer Institute. Medullary Thyroid Carcinoma Clinical Regional Lymph Nodes

TNM Finding v8. NCI Thesaurus. Code C141011.

A clinical finding about one or more characteristics of medullary thyroid carcinoma,

following the rules of the TNM AJCC v8 classification system as they pertain to staging of regional lymph nodes. 